П.М. Перехрестенко, В.М. Самусь, О.М. Аладьєва

Ду «Інститут гематології та трансфузіології НАМН України», Київ

\title{
Стан служби крові України у 2018 р.
}

Служба крові України відноситься до одного з провідних і стратегічних розділів національної системи охорони здоров'я. Застосування компонентів і препаратів крові - чи не головна ланка надання медичної допомоги хворим та постраждалим. Від використання продуктів крові залежить здоров'я, а не рідко і життя пацієнтів. Тому на підставі результатів діяльності закладів служби крові проводиться планування кількісних та якісних показників роботи центрів (станцій) переливання крові.

Ключові слова: донори, донації, кров, плазма, еритроцитна маса, тромбоцити.

\section{Вступ}

Від ефективності роботи закладів служби крові залежить забезпечення компонентами та препаратами крові практично всіх підрозділів клінічної медицини. Сьогодення потребує враховувати ще і події, які відбуваються на Сході України.

Мета - провести аналіз діяльності закладів служби кров України у 2018 р. і надати пропозиції щодо покращення їх роботи.

\section{Об'єкт і методи дослідження}

Проведено аналіз звітів «Галузева статистична звітність форма № 39-здоров», «Звіт Центру служби крові (станції переливання крові), відділення трансфузіології лікувального закладу, установи, лікарні, яка проводить заготівлю крові» областей України, міста Києва та відомчих закладів.

\section{Результати та їх обговорення}

Станом на кінець 2018 р. в Україні функціонували 42 центри (станції) переливання крові (24 обласних, 17 міських та 1 відомчий - Міністерства оборони (МО) України), 303 відділення трансфузіології лікувальних закладів (ВТЛЗ) (з них 6 підпорядковані Міністерству охорони здоров'я (МО3) України та 6 - Національній академії медичних наук (НАМН) України). 73 лікарні проводили заготівлю крові (Перехрестенко П.М. та співавт., 2019).
Кількість центрів (станцій) переливання крові у 2018 р. зменшилася на 1 , ВТЛ3 - на 6 , лікарень, що заготовляють кров, на 3.

Штатних посад у закладах служби крові нараховували 6849,75 (у 2017 р. - 7230,5), із них: лікарів - 1286,25 (у 2017 р. - 1334,25), в тому числі зайнято біологами - 238,25 посади (у 2017 р. 237,5 ), середнього медичного персоналу $-2337,00$ (у 2017 р. $2483,25)$. Укомплектованість штатних посад становила $88,6 \%$ (у 2017 р. $-88,7 \%$ ), із них лікарями $-80,6 \%$ (у 2017 р. - 64,5\%), середнім медичним персоналом - 90,5\% (у 2017 р. - 81,5\%) (Перехрестенко П.М. та співавт., 2019).

\section{Оснащеність закладів служби крові України}

Для проведення автоматичного плазмаферезу та цитаферезу всі заклади служби крові оснащені відповідними апаратами. Лабораторії полімеразної ланцюгової реакції функціонують, на жаль, лише у 5 центрах служби крові (Запорізький - 1, Луганський - 1) та ВТЛЗ МОЗ України - 3.

\section{Донори України}

Як і в попередні роки, спостерігається зменшення кількості донорів. Так, порівняно з 2017 р. їх кількість зменшилася на 6921 особу, або на 1,8\% (Перехрестенко П.М. та співавт., 2019). Зменшення відбулося в багатьох регіонах, крім Вінницької,

Таблиця 1. Донори України

\begin{tabular}{|c|c|c|c|c|c|c|c|}
\hline \multirow{3}{*}{$\begin{array}{c}\text { Найменування регіону } \\
\text { та відомства }\end{array}$} & \multirow{3}{*}{ Загалом } & \multirow{3}{*}{$\begin{array}{c}\text { Частка (\%) } \\
\text { від загальної } \\
\text { кількості населення }\end{array}$} & \multirow{3}{*}{$\begin{array}{c}\text { Динаміка загальної кількості } \\
\text { донорів у } 2018 \text { р. порівняно } \\
\text { з } 2017 \text { р. }\end{array}$} & \multicolumn{4}{|c|}{ Кількість донорів } \\
\hline & & & & \multicolumn{2}{|c|}{ активних } & \multicolumn{2}{|c|}{ резерву } \\
\hline & & & & $\begin{array}{c}\text { Абсолютне } \\
\text { число }\end{array}$ & $\%$ & $\begin{array}{c}\text { Абсолютне } \\
\text { число }\end{array}$ & $\%$ \\
\hline Вінницька обл. & 14326 & 0,92 & 415 & 1153 & 8,05 & 13173 & 91,95 \\
\hline Волинська обл. & 19002 & 1,84 & -248 & 448 & 2,36 & 18554 & 97,64 \\
\hline Дніпропетровська обл. & 35779 & 1,12 & -3847 & 3368 & 9,41 & 32411 & 90,59 \\
\hline Донецька обл. & 16299 & 0,39 & 2233 & 3117 & 19,12 & 13182 & 80,88 \\
\hline Житомирська обл. & 7964 & 0,65 & -755 & 51 & 0,64 & 7913 & 99,36 \\
\hline Закарпатська обл. & 10328 & 0,82 & 2218 & 1086 & 10,52 & 9242 & 89,48 \\
\hline Запорізька обл. & 24604 & 1,44 & -113 & 1947 & 7,91 & 22657 & 92,09 \\
\hline Івано-Франківська обл. & 8478 & 0,62 & -2495 & 589 & 6,95 & 7889 & 93,05 \\
\hline Київська обл. & 11590 & 0,66 & -1502 & 1890 & 16,31 & 9700 & 83,69 \\
\hline Кіровоградська обл. & 8654 & 0,92 & 74 & 392 & 4,53 & 8262 & 95,47 \\
\hline Луганська обл. & 10465 & 0,49 & 83 & 220 & 2,10 & 10245 & 97,90 \\
\hline Львівська обл. & 20763 & 0,83 & -1661 & 163 & 0,79 & 20600 & 99,21 \\
\hline Миколаївська обл. & 17004 & 1,50 & 3317 & 1924 & 11,31 & 15080 & 88,69 \\
\hline Одеська обл. & 20233 & 0,85 & -665 & 4300 & 21,25 & 15933 & 78,75 \\
\hline Полтавська обл. & 14101 & 1,01 & 170 & 801 & 5,68 & 13300 & 94,32 \\
\hline Сумська обл. & 14870 & 1,38 & 6924 & 9627 & 64,74 & 5243 & 35,26 \\
\hline Тернопільська обл. & 7993 & 0,77 & -137 & 39 & 0,49 & 7954 & 99,51 \\
\hline Харківська обл. & 21172 & 0,80 & 1592 & 6142 & 29,01 & 15030 & 70,99 \\
\hline Херсонська обл. & 7403 & 0,71 & -270 & 2677 & 36,16 & 4726 & 63,84 \\
\hline Хмельницька обл. & 20887 & 1,66 & -3148 & 2170 & 10,39 & 18717 & 89,61 \\
\hline Черкаська обл. & 10238 & 0,85 & -1998 & 1227 & 11,98 & 9011 & 88,02 \\
\hline Чернівецька обл. & 6048 & 0,67 & -99 & 802 & 13,26 & 5246 & 86,74 \\
\hline Чернігівська обл. & 7969 & 0,80 & -1491 & 767 & 9,62 & 7202 & 90,38 \\
\hline м. Київ & 21644 & 0,74 & -1235 & 1148 & 5,30 & 20496 & 94,70 \\
\hline Загалом & 365712 & 0,87 & -4660 & 46427 & 12,69 & 319285 & 87,31 \\
\hline ВТЛЗ М03 України & 9081 & 0,02 & -2661 & 2174 & 23,94 & 6907 & 76,06 \\
\hline МО України & 4190 & 0,01 & 616 & 257 & 6,13 & 3933 & 93,87 \\
\hline ВТЛЗ НАМН України & 6370 & 0,02 & -216 & 1230 & 19,31 & 5140 & 80,69 \\
\hline Україна & 385353 & 0,92 & -6921 & 50088 & 13,00 & 335265 & 87,00 \\
\hline
\end{tabular}


Таблиця 2. Порівняльна характеристика донацій крові, плазми та клітин крові

\begin{tabular}{|c|c|c|c|c|c|c|c|c|}
\hline \multirow{3}{*}{$\begin{array}{c}\text { Найменування perioну } \\
\text { та відомства }\end{array}$} & \multirow{2}{*}{\multicolumn{2}{|c|}{ Загалом донацій }} & \multicolumn{6}{|c|}{ У тому числі } \\
\hline & & & \multicolumn{2}{|c|}{ кроводач } & \multicolumn{2}{|c|}{ плазмодач } & \multicolumn{2}{|c|}{ клітин крові } \\
\hline & 2017 p. & 2018 p. & 2017 p. & 2018 p. & 2017 p. & 2018 p. & 2017 p. & $2018 p$. \\
\hline Вінницька обл. & 16958 & 16752 & 16538 & 16206 & 231 & 186 & 189 & 360 \\
\hline Волинська обл. & 26197 & 22809 & 24131 & 21346 & 1747 & 1246 & 319 & 217 \\
\hline Дніпропетровська обл. & 58494 & 53452 & 51857 & 49496 & 5779 & 2610 & 858 & 1346 \\
\hline Донецька обл. & 28439 & 25583 & 20511 & 18121 & 7928 & 7393 & 0 & 69 \\
\hline Житомирська обл. & 10455 & 9928 & 9888 & 9112 & 267 & 354 & 300 & 462 \\
\hline Закарпатська обл. & 12418 & 13373 & 12067 & 12800 & 260 & 410 & 91 & 163 \\
\hline Запорізька обл. & 34128 & 33670 & 26420 & 26413 & 7478 & 6904 & 230 & 353 \\
\hline Івано-Франківська обл. & 14493 & 11666 & 13849 & 10967 & 348 & 415 & 296 & 284 \\
\hline Київська обл. & 16272 & 14657 & 15853 & 14253 & 15 & & 404 & 404 \\
\hline Кіровоградська обл. & 10775 & 11281 & 10612 & 11146 & 57 & 3 & 106 & 132 \\
\hline Луганська обл. & 10382 & 10465 & 9759 & 9715 & 578 & 649 & 45 & 101 \\
\hline Львівська обл. & 23499 & 22210 & 22525 & 21248 & 409 & 281 & 565 & 681 \\
\hline Миколаївська обл. & 25692 & 22910 & 23030 & 20942 & 2479 & 1653 & 183 & 315 \\
\hline Одеська обл. & 27102 & 26699 & 24444 & 24581 & 2258 & 1473 & 400 & 645 \\
\hline Полтавська обл. & 20157 & 20591 & 18179 & 18829 & 1624 & 1260 & 354 & 502 \\
\hline Рівненська обл. & 12053 & 11094 & 11865 & 10649 & 11 & 273 & 177 & 172 \\
\hline Тернопільська обл. & 10492 & 9851 & 8222 & 8993 & 2248 & 760 & 22 & 98 \\
\hline Харківська обл. & 29113 & 32379 & 27444 & 29878 & 1408 & 1583 & 261 & 918 \\
\hline Херсонська обл. & 11165 & 12031 & 10260 & 11311 & 725 & 381 & 180 & 339 \\
\hline Хмельницька обл. & 32199 & 28422 & 31726 & 27920 & 266 & 317 & 207 & 185 \\
\hline Черкаська обл. & 15156 & 12816 & 14091 & 11307 & 194 & 91 & 871 & 1418 \\
\hline Чернівецька обл. & 9665 & 9411 & 9407 & 8854 & 139 & 345 & 119 & 212 \\
\hline Чернігівська обл. & 13431 & 11353 & 12606 & 10723 & 732 & 446 & 93 & 184 \\
\hline м. Київ & 28293 & 26338 & 26274 & 25019 & 854 & 207 & 1165 & 1112 \\
\hline Загалом & 550860 & 535219 & 459602 & 436605 & 83637 & 87578 & 7621 & 11036 \\
\hline ВТЛЗ М03 України & 16971 & 14633 & 14246 & 11853 & 574 & 690 & 2151 & 2090 \\
\hline МО України & 4024 & 4575 & 3863 & 4472 & & & 161 & 103 \\
\hline ВТЛЗ НАМН України & 9225 & 8603 & 8995 & 8234 & 162 & 285 & 68 & 84 \\
\hline Україна & 581080 & 563030 & 486706 & 461164 & 84373 & 88553 & 10001 & 13313 \\
\hline
\end{tabular}

Донецької, Закарпатської, Кіровоградської, Луганської, Полтавської, Харківської, Сумської та Миколаївської областей.

Середня частка донорів від загальної кількості населення Украіни у 2018 р. становила 0,92\% (у 2017 р. - 0,93\%). Вище середнього по Україні цей показник був у Волинській $(1,84 \%)$, Хмельницькій $(1,66 \%)$, Миколаївській $(1,50 \%)$, Запорізькій $(1,44 \%)$, Сумській $(1,38 \%)$, Дніпропетровській $(1,12 \%)$, найнижчий -у Донецькій (0,39\%), Луганській (0,49\%), Івано-Франківській (0,62\%), Житомирській $(0,65 \%)$, Київській $(0,66 \%)$, Чернівецькій $(0,67 \%)$ областях.

Незважаючи на зменшення загальної кількості донорів, відзначають зміни у структурі донорських кадрів. Зросла кількість активних донорів із 47555 у 2017 р. до 50088 - у 2018 р. Збільшилася кількість донорів клітин крові 37142 у 2017 р. до $8736-$ у 2018 р., що у відсотках від загальної кількості донорів становить 1,82\% у 2017 р. до 2,27\% - у 2018 р. (табл. 1).

У 2018 р. зменшилася на 4941 особу кількість донорів плазми крові. Імунні донори були лише уХмельницькій області (3), ізоімунні - у Сумській (120), Донецькій (6), Вінницькій (4), Запорізькій (3), Черкаській (1) областях.

Перехід 13 обласних центрів (станцій) переливання крові та відомчих ВТЛЗ лише на одержання плазми крові методом автоматичного плазмаферезу дозволив покращити ситуацію з використанням еритроцитної маси. Зменшилася кількість заготовленої еритроцитної маси з 121 926,3 лу 2017 р. до 117 732,9 л-у 2018 р. і внаслідокцього - суттєво зменшилася кількість списаної узв'язку із закінченням терміну зберігання 314 102,6 л у 2017 р. до 10003,2 л-у 2018 р. При всій неоднозначності ситуації відзначимо явний перехід від загальних показників до показників якості.

Загальна кількість донацій становила 563030 (що на 18050 менше, ніж у 2017 р.), з них кроводач - 461 164, плазмодач - 88 553, донацій клітин крові - 13313 (табл. 2). На 1000 населення України у 2018 р. було 12,75 (у 2017 р. - 13,05) донацій, з них: кроводач 10,4 (у 2017 р. - 10,89), плазмодач 2,09 (у 2017 р. - 1,98), донацій клітин крові 0,26 (у 2017 р. - 0,18). У країнах Європи цей показник становить 36 (Чугрієв А.М., 2017).

Зменшується також кількість заготовленої консервованої донорської крові. У 2018 р. одержано 253 708,6 л, що на 9963,7 л менше порівняно з 2017 p.

Компоненти крові. Заготівля плазми крові

У 2018 р. заготовлено 159 479,3 л плазми крові (що на 2660,1 л більше, ніж у 2017 р.). Із 1 л консервованої крові одержано 474,4 мл $(47,4 \%)$ плазми крові.
Автоматичним плазмаферезом одержано 50 367,2 л (31,6\%) від всієї заготовленої плазми крові (у 2017 р. ця частка становила $30,4 \%)$, мануальним - 4002,7 л (2,5\%). Загалом методом плазмаферезу отримано 54 369,9 л (34,1\%) плазми крові.

Середня доза плазми крові становила при автоматичному плазмаферезі 691,0 мл (у 2017 р. - 668,7 мл), при проведенні однократного мануального плазмаферезу $-274,8$ мл, двократного - 545,3 мл.

Брак плазми крові від усієї заготовленої у 2018 р. становив 3,9\% (у 2017 р. - 4,8\%), тобто 6293,9 л виявилися непридатними для використання.

3 метою зменшення передачі гемотрансфузійних інфекцій від донора до пацієнта проводили карантинізацію плазми крові (МОЗ України, 2005). У 2018 р. на карантинізації знаходилось 152370,7 л (95,5\%) від усієї заготовленої плазми крові. Лікувальнопрофілактичні заклади використали для трансфузій 75 903,0 л $(49,8 \%)$ карантинізованої плазми крові (2017 р. - 81 814,7 л $(54,8 \%))$. Лише 7979,7 л (3,4\%) перероблено на препарати, у 2017 р. - 17357,8 л (7,1\%). На рисунку представлено частку карантинізованої плазми крові від усієї заготовленої. Максимальна частка карантинізованої плазми крові у Хмельницькій $(99,5 \%)$,

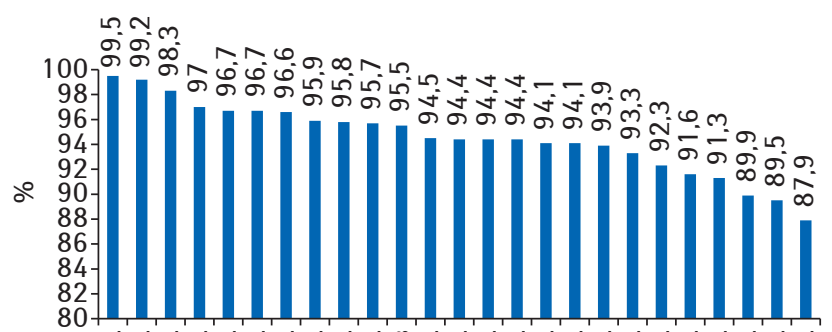
๒ั்

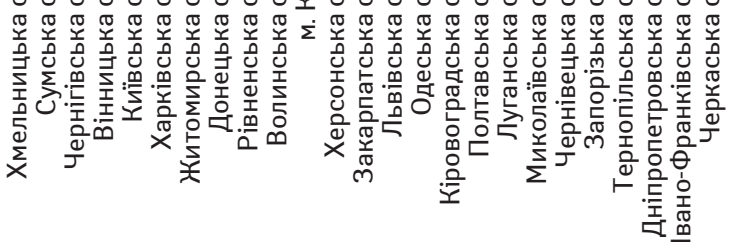

Рисунок. Частка закладеної на карантинізацію плазми крові від усієї заготовленої (\%) 
Сумській (99,2\%), Чернігівській (98,3\%), Вінницькій (97,0\%), Київській $(96,7 \%)$ областях.

Спостерігається позитивна тенденція щодо збільшення кількості доз заготовленого концентрату тромбоцитів. У 2018 р. заготовлено 37 652,2 дози тромбоцитів, із них: концентрату з 500 мл консервованої крові - 10567,2 дози, аферезнихтромбоцитів - 27 085,0 доз. Використано для трансфузій у лікувально-профілактичних закладах 85,4\% (32 148,0 доз) заготовленого концентрату тромбоцитів.

\section{Висновки}

Служба крові України як одна зі стратегічних галузей медицини потребує державної уваги та корінного поліпшення діяльності. У період 2018-2019рр., згідно з Розпорядженням Кабінету Міністрів України від 20.02.2019 р. № 120-р, розроблено та затверджено Стратегію розвитку національної системи крові на період до 2022 року та затверджено план заходів щодо її реалізації.

\section{Список використаної літератури}

м03 України (2005) Наказ М03 України від 01.08.2005 р. № 385 «Про інфекційну безпеку донорської крові та її компонентів" (https://zakon.rada.gov. ua/laws/show/20895-05).

Перехрестенко П.М., Горяінова Н.В., Самусь В.М., Аладьєва О.М. (2019) Діяльність закладів служби крові України у 2018 році: Довідник. ДІА, Київ, 72 с.

Чугрієв А.М. (2017) Макрооцінка діяльності регіональних служб крові України. Україна. Здоров'я нації, 3(44): 292-297 (http://nbuv.gov.ua/UJRN/Uzn_2017_3_51).

\section{Состояние службы крови Украины в 2018 г. П.М. Перехрестенко, В.Н. Самусь, Е.М. Аладьева}

Резюме. Служба крови Украины относится к одному из ведущих и стратегических разделов национальной системы здравоохранения.
Применение компонентов и препаратов крови - едва ли не главное звено оказания медицинской помощи больным и пострадавшим. Отиспользования продуктов крови зависит здоровье, а нередко и жизнь пациентов. Поэтомуна основании результатов деятельности учреждений службы крови проводится планирование количественных и качественных показателей работы центров (станций) переливания крови.

Ключевые слова: доноры, донации, кровь, плазма крови, эритроцитная масса, тромбоциты.

\section{State of the Ukrainian blood service in 2018 P.M. Perekhrestenko, V.M. Samus, O.M. Aladyeva}

Summary. The Blood Service of Ukraine is one of the leading and strategic sections of the national healthcare system. The use of blood components and preparations is perhaps the main link in the provision of medical care to the sick and injured. The health of patients, and often their lives, depends on the use of blood products. Therefore, based on the results of the activities of the blood service institutions, the planning of quantitative and qualitative indicators of the work of blood transfusion centers (stations) is carried out.

Key words: donors, donations, blood, plasma, erythrocyte mass, platelets.

\section{Адреса для листування:}

Перехрестенко Петро Михайлович

04060, Київ, вул. Максима Берлинського, 12

Державна установа «ннститут гематології

та трансфузіології НАМН України»

E-mail: igt.org@ukr.net

Одержано 30.09.2019

\section{РЕФЕРАТИВНА ІНФОРМАЦІЯ}

\section{Фібриляція передсердь: електрична}

чи фармакологічна кардіоверсія?

Фібриляцію передсердь (ФП) виявляють у 1-2\% популяції, і цей показник, імовірно, зростатиме у наступні 50 років. У пацієнтів з гострим інсультом систематичне електрокардіографічне (ЕКГ) моніторування може допомогти виявити ФП у одного із двадцяти пацієнтів, що значно більше тієї кількості осіб з ФП, яку можна було б виявити за допомогою стандартної ЕКГ 12 відведеннях. Але ФП може тривалий час залишатися недіагностованою («німа» ФП), і багато пацієнтів з ФП ніколи не будуть госпіталізовані. Таким чином, істинна поширеність ФП, очевидно, ближче до 2\% популяції.

Поширеність ФП зростає з віком, збільшуючись від $<0,5 \%$ серед осіб віком 40-50 років до 5-15\% серед осіб віком 80 років. Захворювання частіше виникає у чоловіків, ніж у жінок. Після досягнення 40-річного віку пожиттєвий ризик розвитку ФП у майбутньому становить близько 25\%. Поширеність і захворюваність на ФП упопуляціях людей, які не належать до представників європеоїдної раси, вивчені гірше. Захворюваність на ФП зростає (13\% в останні два десятиріччя), згідно з інформацією Міністерства охорони здоров'я України

ФП є найчастішою аритмією, лікування проводять у відділенні невідкладної медичної допомоги. Основними підходами в лікуванні при аритмії є контроль частоти скорочень шлуночків або відновлення синусового ритму. Причому в останньому випадку можливе використання як фармакологічної, так і електричної кардіоверсії, а вибір методу найчастіше визначається сформованими традиціями в конкретному центрі. У зв'язку з цим метою рандомізованого дослідження RAFF2 стало порівняння ефективності електричної або фармакологічної в поєднанні з електричною (за необхідності) кардіоверсією у пацієнтів, госпіталізованих з ФП у відділення невідкладної допомоги. Вторинна мета - порівняння ефективності двох положень прокладки (передньозаднього та передньобічного) при проведенні електричної кардіоверсії.

Рандомізоване дослідження проводили в 11 центрах Канади. Включали пацієнтів з гострим нападом ФП, тривалістю не менше 3 год і не більше 48 год в тому разі, якщо пацієнт не отримував антикоагулянтної терапії, і не більше 7 днів, якщо отримував. Ви- ключали з дослідження гемодинамічно нестабільних пацієнтів, осіб з гострим коронарним синдромом, пневмонією, іншими тяжкими захворюваннями, що затруднюють порівняння двох підходів.

Пацієнтів було рандомізовано на дві групи (два протоколи): фармакологічна кардіоверсія - внутрішньовенне введення прокаїнаміду ( 15 мг/кг протягом 30 хв), далі за необхідності - проведення електричної кардіоверсії або відразу електрична кардіоверсія. За основну кінцеву точку було вибрано частоту конверсії аритмії в синусовий ритм. Для визначення вторинної мети дослідження проаналізовано пацієнтів другого протоколу з метою порівняння передньозаднього та передньобічного положень прокладки кардіовертера.

Обидві стратегії були високоефективними, швидкими та безпечними для відновлення синусового ритму для пацієнтів у відділенні невідкладної медичної допомоги з епізодом гострої ФП. Загалом у дослідження було включено 396 пацієнтів. У групі, де застосовувалася фармакологічна, а при її неефективності-електрична кардіоверсія, частота конверсії в синусовий ритм становила $96 \%$. При цьому у $52 \%$ синусовий ритм відновився після інфузії антиаритмічного препарату. Частота відновлення ритму в групі електричної кардіоверсії становила $92 \%$; для різниці $\mathrm{p}=0,07$. У дослідженні не виявлено суттєвої різниці між передньозаднім та передньобічним положенням прокладки кардіовертера.

Результати представленого дослідження демонструють рівність підходів фармакологічної з подальшою електричною кардіоверсіями або тільки електричної кардіоверсії у пацієнтів із гострим епізодом ФП.

Звертає увагу, що у половини пацієнтів групи фармакологічна + електрична кардіоверсія ритм відновлювався вже після інфузії антиаритмічного препарату.

Рішення про спосіб кардіоверсії має прийматися безпосередньо пацієнтом. При цьому перевагами електричної кардіоверсії $€$ її швидкість, тоді як фармакологічної + електричної - можливість уникнути седації в половині випадків.

Stiell I.G., Sivilotti M.L.A., Taljaard M. (2020) Electrical versus pharmacological cardioversion for emergency department patients with acute atrial fibrillation (RAFF2): a partial factorial randomised trial. Lancet, Feb. 1.

Анна Хиць 